\title{
The Impacts of Emotional Intelligence on Individual Performance and Work-Life Balance: A Conceptual Exploration
}

Azzie T Joyce, Hamrila A. Latif, M Monzer Rahaman, Hridoy Saha

To Link this Article: http://dx.doi.org/10.6007/IJARAFMS/v11-i3/10990 DOI:10.6007/IJARAFMS/v11-i3/10990

Received: 20 July 2021, Revised: 22 August 2021, Accepted: 09 September 2021

Published Online: 16 September 2021

In-Text Citation: (Joyce et al., 2021)

To Cite this Article: Joyce, A. T., Latif, H. A., Rahaman, M. M., \& Saha, H. (2021). The Impacts of Emotional Intelligence on Individual Performance and Work-Life Balance: A Conceptual Exploration. International Journal of Academic Research in Accounting Finance and Management Sciences, 11(11), 801-812.

Copyright: (c) 2021 The Author(s)

Published by Human Resource Management Academic Research Society (www.hrmars.com)

This article is published under the Creative Commons Attribution (CC BY 4.0) license. Anyone may reproduce, distribute, translate and create derivative works of this article (for both commercial and non-commercial purposes), subject to full attribution to the original publication and authors. The full terms of this license may be seen at: http://creativecommons.org/licences/by/4.0/legalcode

Vol. 11, No. 3, 2021, Pg. 801 - 812

Full Terms \& Conditions of access and use can be found at http://hrmars.com/index.php/pages/detail/publication-ethics 


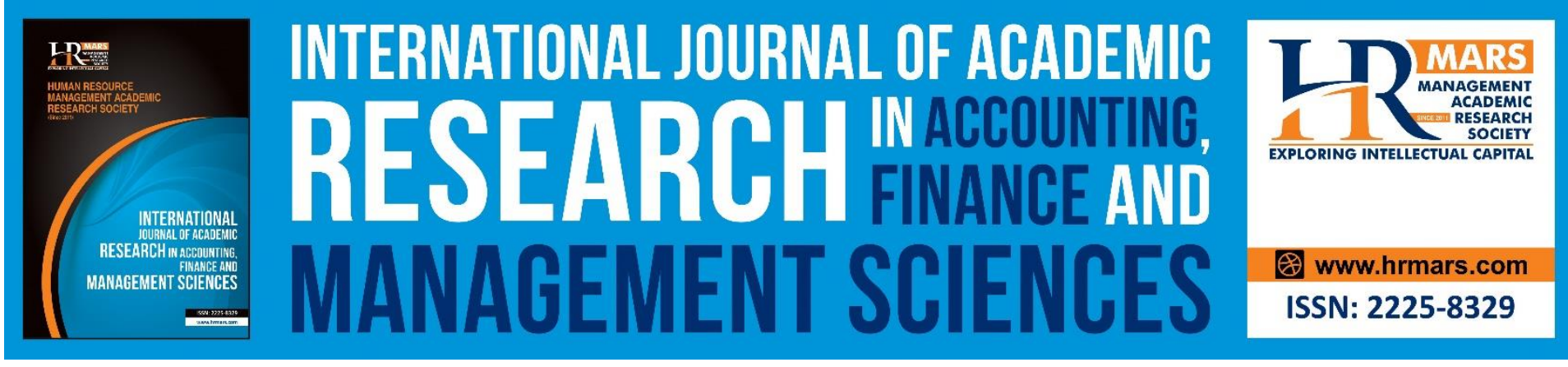

\title{
The Impacts of Emotional Intelligence on Individual Performance and Work-Life Balance: A Conceptual Exploration
}

\author{
Azzie T Joyce, Hamrila A. Latif, M Monzer Rahaman, Hridoy \\ Saha \\ Universiti Malaysia Sarawak (UNIMAS) \\ Email:monzerrahaman@gmail.com
}

\begin{abstract}
Emotional Intelligence (EI) 's impact on individuals' performance is a topic of interest among academics and is being utilized to explain its richness in professional and social connections. Meanwhile, work-life has been a crucial discussed topic among researchers and a focus of exploration across countries and spectrums. However, individual performance, as defined in this conceptual exploration in terms of emotional intelligence, has an impact on an individual's response to changes in workload, organizational commitment, and work engagement; where the term work-life balance is used to explain the impact of an individual's emotional intelligence on maintaining balance among personal life, family domains, and work domain. Although such studies have focused on the relationship among specific factors, there is limited research on how effective leadership is moderating these variables. This study, therefore, proposes a more comprehensiveness through Bar-On's model, ability model, and expectancy theory to expand and clarify the relationship between the variables and moderator. This paper claims that emotional intelligence is crucially nested in leadership, individual work performance, and the balance between work-life. Hence, the study proposed a theoretical framework that bridges El with individual performance and work-life balance, where leadership is moderating all those variables.
\end{abstract}

Keywords: Emotional Intelligence, Workload, Organizational Commitment, Employee Engagement, Work-Life Balance, Leadership, Bar-On's model, Ability Model, Expectancy Theory.

\section{Introduction}

Emotional intelligence (EI) term has been advanced to describe the set of personal traits enhancing professional and social relationships. Developed by Goleman (1995) and Mayer et al (1997), El elements encompass the interactions between one's professional and personal life. Empirical evidence indicates that El impacts work-life balance measured by personal-family-work satisfaction (Sharma, 2014; Praya et al., 2019). Besides, emotional intelligence (EI) is a popular topic in organizational behavior and leadership to predict 
MANAGEMENT SCIENCES

Vol. 11, No. 3, 2021, E-ISSN: 2225-8329 @ 2021 HRMARS

individual performance in various contexts, explicitly impacting task response, commitment, and engagement towards the organization. Furthermore, other studies have also supported the mentioned findings and indicate El's ability to influence social interactions and affect one's ability to perform in an organization (Cropanzano et al., 2017; Miao et al., 2018).

Maintaining a work-life balance always has been an issue in managing all the prospects at any extent of any individual's life. In a broader sense, work-life balance defines the satisfaction level of an individual's involvement in multiple roles both in work and personal life (Brough et al., 2020). This term describes the acts required to implement at the workplace to realize and support employees' necessities to achieve a balance in work-life and meet both family and work demands. Numerous researches suggest that individuals with higher emotional intelligence are less exposed to work-life conflict and achieve higher work-life balance (Shylaja \& Prasad, 2017), since individuals with higher emotional intelligence can cope with any consequences compared to those with less El, for instance, overcoming stress in any situation (Sunil \& Rooprai, 2009).

The management has to be very concerned about their employees' work-life balance as they are often incompetent to maintain it. Organizations failing to provide adequate opportunities to employees to support a balanced work-life are facing them towards a situation of being dissatisfied and unproductive and hence a rise in attrition rates. On the other hand, employees with higher El and having a balance between work and life tend to influenceothers' emotions, which results in a satisfied professional and personal life (Koubova et al., 2013).

Usually, within business domain administration, emotions are granted as negative aspects as they can negatively affect making decisions in business but in terms of El regarded as positive sense since its usefulness in predicting positive organizational outcomes. According to Jordan et al (2002), people with higher El would deal better with their adverse emotional reactions to bring about more productive results.

Emotional intelligence can influence social interactions, which have implications for organizational leadership and effective leadership. Leaders conveying a higher level of El have an awareness of their own and others' emotional feelings, which aids them to solute any routine hurdles and provide support to employees with pressure in the workplace (McClellan et al., 2017). Studies indicated that in terms of El, leadership is more effective in optimism and supportive behavior and results in performance improvement rather than negative impacts occurring from frustrations (Boyatzis, 2018). Besides recognizing and managing emotions, El also enables employee development. Due to that, leaders practice to improve employees' skills to make employees' performance more adequate to their assigned tasks for the needs and success of the organization (Bar-On et al., 2004).

Lam and Kirby (2002) indicated Emotional Intelligence as the best tool to predict employee performance as it understands and handles employees' emotions in the desired manner to forecast their productivity. Besides, individuals who convey higher emotional intelligence can regulate their own emotions accurately, use this in decision making, and enhance their performance by bringing changes to their behavior (Bozionelos \& Singh, 2017). As emotional intelligence enables individuals to deal with their emotions in the workplace, employees' emotional stimulation can be modulated from their surroundings through response-focused emotion regulation by prolonging, diminishing, curtailing, or intensifying certain emotions (Grandey, 2000).

This study aims at El's impact on work-life balance and individual performance. Besides exploring the effectiveness of leadership as a moderator on the variables mentioned 
MANAGEMENT SCIENCES

Vol. 11, No. 3, 2021, E-ISSN: 2225-8329 @ 2021 HRMARS

above, this study also focuses on specific criteria, for instance, regulation, self-judgment, family life, personal life, organizational commitment, and employee engagement.

This study is sorted as a brief literature overview, theoretical framework, hypothesis testing, and accompanied by the conclusion.

\section{Literature Review}

The current theoretical approaches include the ability model, Bar-On's model, and expectancy theory to describe and valuable insight into how emotional intelligence impacts an individual's work-life balance and performance, where leadership is moderating all those variables mentioned above.

Mayer et al (2000) referred to El as the potential to use, understand, perceive, regulate and express emotions in self and others. Salovey and Mayer's (1990) concept about El focuses specifically on emotional abilities to link cognition and emotion and defined EI through the ability-based model. The ability model is appropriate for this study since emotional intelligence has been perceived as an interrelated skill that enables one to efficiently, accurately, and emotionally process information (Mayer et al., 1999). The ability model sees El from one's emotional stance that is integral for personal growth. The ability model plays a role in emotional intelligence, where the individual that is related to the emotional aspect of this ability model from a workplace perspective. With this ability, the individual will start to understand and be aware of their satisfaction. At this level, individuals begin to understand that either work or work-life balance is essential.

Emotional intelligence highlights the necessity of emotional expression and visualizesthe outcomes of emotionally intelligent behavior (Bar-On, 2006). Emotional expression and awareness are vital components of El (Goleman, 1995; Bar-On, 1997), and lighting the fact optimal adaption represents a crucial area of inquiry in positive psychology (Luthans \& Youssef-Morgan, 2017). Social and Emotional competencies, facilitators, and skills determine someone's effectiveness to know and express the self-understanding of a relation to others and ability to cope up with daily demands as focused on Bar-On's model. As for BarOn's model, individuals start to expand psychological assessment at this level. Individuals want to include a broad range of contributors towards behavior and performance. Besides, Bar-On's model, other current models describing El also have supported the requirement of the ability to thrive in addition to surviving merely. (Bar-On, 1997; Goleman, 1998).

Evolved in the 20th century as a fundamental paradigm to study human attitude and behavior in organizational settings (Lawer III \& Suttle, 1973), the expectancy theory of motivation was initially developed by Vroom (1964) explains the procedures an individual use in decision making on a variety of behavioral alternatives. Expectancy theory postulates that a combination of an individual's expectations for subjective task value and success in particular domains motivate the achievement-related choices (Leaper, 2011). It is presented as:

\section{Motivation force $=$ Expectancy $\times$ instrumentality $\times$ valence}

Expectancy theory is relevant for this study when once a person has a good performance, emotion, work-life balance, an individual's level of satisfaction will increase. According to Isaac et al. (2001), the model also found that job behavior is a joint function of ability, role perception, and motivation. Expectancy theory will take place at this rate. It involves employees considering if they are good at performance and can handle work-life balance; thus, they will be appropriately rewarded by their leader. 
MANAGEMENT SCIENCES

Vol. 11, No. 3, 2021, E-ISSN: 2225-8329 @ 2021 HRMARS

Supported by the theories as mentioned earlier and previous relevant literature, a theoretical framework is formulated, and from that, the hypothesis is as follows:

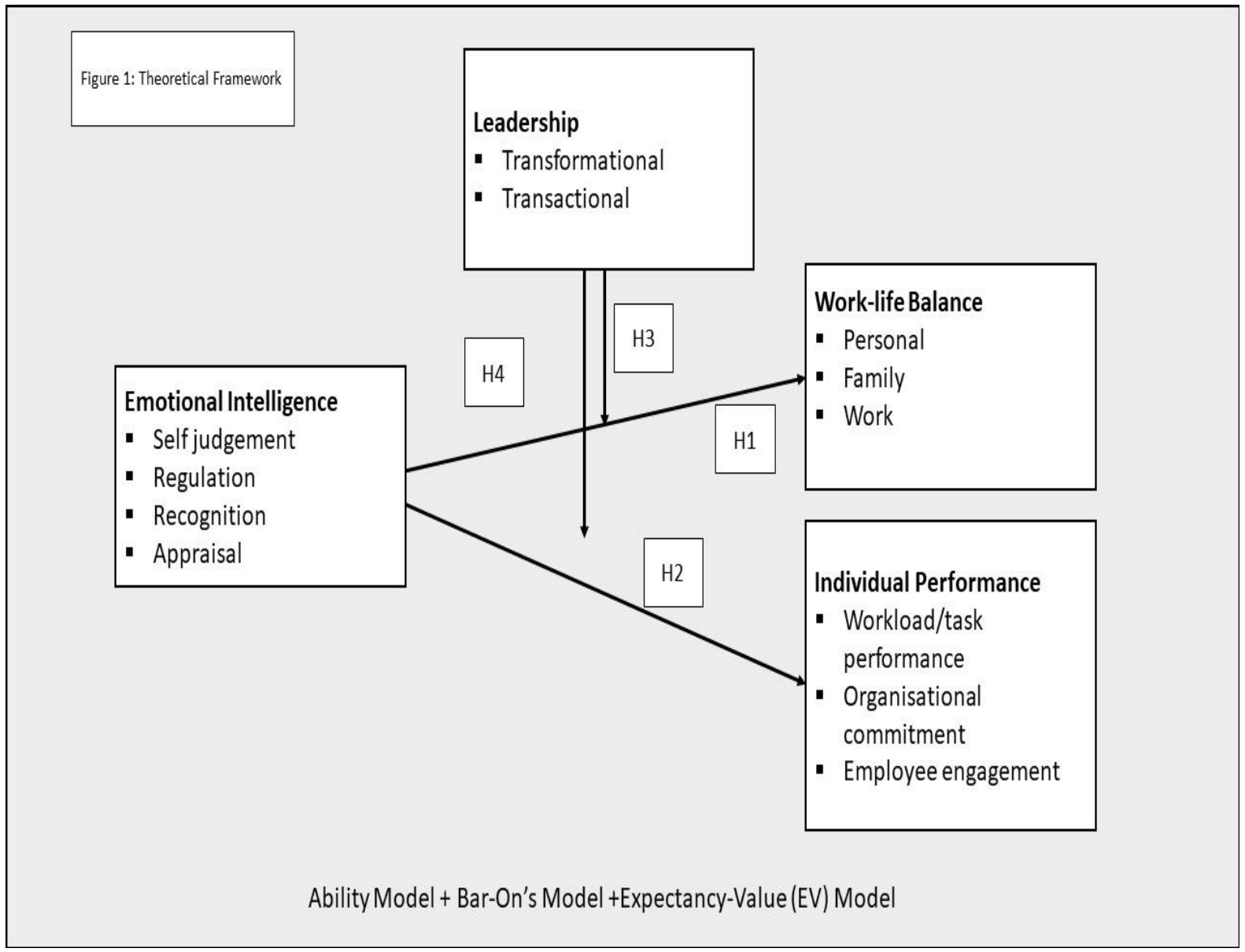

Formation of Hypothesis

\section{Emotional Intelligence and Work-life Balance}

$\mathrm{H}_{1}$ : There is a positive relationship between emotional intelligence and work-life balance.

Observations from Emotional intelligence influence on dimensions of a work-life balance were found weakly related but significant. Parkes and Langford (2008) found a significant and positive relationship between organizational support and job engagement to a balanced work-life. Factors such as the expression of emotions and appraisal have an enormous influence on work-life balance to facilitate individual performance (Gupta, 2016).

Employees can monitor and effectively manage their emotions while possessing El. Rangreji (2010) found that El plays a vital role in employees' ability to become productive and enjoys the relationships within an organization. Therefore, the hypothesis mentioned above expresses the positive relationship between emotional intelligence and work-life balance.

\section{$\mathrm{H}_{2}$ : There is a positive relationship between Emotional Intelligence and Individual Performance.}

A study carried out by Day and Carroll (2004) on the correlation between El and individual performance by focusing on the interaction between self and other emotional dimensions and found a positive relationship. As for this present study, emotional intelligence 
MANAGEMENT SCIENCES

Vol. 11, No. 3, 2021, E-ISSN: 2225-8329 @ 2021 HRMARS

has been conceptualized in adherence to Mayor and Salovey's (1995) four-branch model, which was measured based on self-reported measures. This self-reported measure is for testing purposes upon weighing in its link with job performance and its significant incremental validity over cognitive and personality measures (Joseph et al., 2015).

Testing the impact of combined emotional intelligence on job performance can better tie in with the dynamics of emotional procedures (Pekaar et al., 2017). All emotional symptoms may influence an employee's performance since emotional intelligence is a vital element that generates productive working conditions (Smigla \& Pastoria, 2000; Sony \& Mekoth, 2016). Based on the above assumption and previous studies, the hypothesis mentioned above expresses the positive relationship between emotional intelligence and individual performance.

\section{$H_{3}$ : Leadership moderates the relationship between Emotional Intelligence and Work-life Balance.}

Transactional leadership differs from transformational leadership. Transactional leadership complies based on constructive transactions or contingent reward, laissez-faire management, and management-by-exception. On the other hand, transformational leadership comprises inspirational motivation, intellectual stimulation, individualized consideration, and idealized influence. However, in this study, leadership measures both transactional and transformational.

El has a strong relationship with work-life balance, but a good leader can change the cause-effect relationship between two variables. It depends on the leader's role in the workplace. Good work and an enjoyable environment have a good influence on all parties, regardless of leaders or workers (Janssen \& Van Yperen, 2004). The work environment that surrounds an employee can affect the employee while performing their duties in their workplace (Demsky et al., 2019). Therefore, this study supports the hypothesis that leadership moderates the relationship between emotional intelligence and work-life balance.

\section{$\mathrm{H}_{4}$ : Leadership moderates the relationship between Emotional Intelligence and Individual Performance.}

The success of an organization relies on the ability of a leader to optimize its human resource domain. A leader with higher El can successfully identify and handle his emotions. Apart from displaying gratification delay and self-control, they may serve as role models, thus gaining respect and building trust among followers. Leaders with higher El substantially impact individual and employee performance, and this notion is in line with the gist of idealized influence. A successful leader sees the significance of a worker to hit the organizational target and reckons the importance of motivation in attaining this goal (LakaMathebula, 2005).

Most people probably have some leadership ability, although the potential may be severely limited. Self-acceptance and leadership effectiveness are related (Hogan et al., 1994), whereas self-esteem and leadership behaviors vary according to individuals. McCollKennedy and Anderson (2002) claimed to have a positive relationship between leadership and organizational performance. Emotional intelligence and individual performance have a strong relationship; thus, good leaders will come. Hence, this study supports the hypothesis that 
MANAGEMENT SCIENCES

Vol. 11, No. 3, 2021, E-ISSN: 2225-8329 @ 2021 HRMARS

leadership moderates the relationship between emotional intelligence and individual performance.

\section{Emotional Intelligence (EI)}

Researchers and popular press identified El as an important element for effective leadership. Golemen (1998) mentioned, "the most effective leaders are alike in one crucial way; they all have a high degree of what has come to be known as emotional intelligence." Other researchers Druskat and Wolff (2001) quoted, "By now, most executives have accepted that emotional intelligence is as critical as IQ to an individual's effectiveness."

Effective leadership and job performance are such organizational outcomes, is one of the basic and important concepts of El (Cherniss, 2010). Numerous researchers support that emotional intelligence plays an important role in work-related issues (Lan et al.,2017; Extremera et al., 2018). Gannon \& Ranzijn (2005) suggested in their study that El is accountable for incremental validity and notable studies indicating the existing link between emotion, performance, and social competence (ESC) (Emmerling et al., 2012).

\section{Work-life Balance}

Work-life balance describes practices found in a workplace that supports and reckons employee demands towards attaining the work-life balance. This idea refers to one's perception that work and nonwork activities are compatible and encourage growth by adhering to the current life priorities one seeks. In a vast spectrum, work-life balance reflects the satisfactory level achieved by an individual due to involvement in multiple functions and roles. Beauregard and Henry (2009) found work-life imbalance accountable for more absenteeism in the workplace and poor work performance.

From an organizational standpoint, Kreiner et al (2013) stated that employees might perform better in the workplace if they balance their family domains and work effectively. Balanced family life and work have been typically associated with higher organizational commitment and enhanced job gratification (Wayne et al., 2017). In this regard, several researchers have emphasized work-life balance management, which is a critical management strategy to improve the performance of employees and their performance in an organization. Additionally, Carmeli (2003) empirically discovered that El directly affects work-life balance and an individual's performance.

\section{Individual Performance}

Individual performance is a core concept within organizational psychology, although not the only prerequisite for success and career development. Generally, high performance gives an individual a better career opportunity and getting promotions easily within an organization compared to low performers. (Trevor et al., 1997). Conversely, low performance and failure to achieve goals are possibly experienced as dissatisfaction or counted as a personal failure. (Sonnentag, 2003).

Workplace being a part of an individual's life that affects individual's personal life and, ultimately, their respective community's well-being (Harter et al., 2003). The behavior at the workplace will affect workers' behavior within the relationship, and their routine life includes family and home, which are also influenced by emotions. If people feel stressed and have an over workload, they will be unable to manage their work well and have less quality time for themselves and their families (Rafnsdóttir \& Heijstra, 2013). In the competitive environment, work has been extended from singular to multiple duties, and the workload originated from 
MANAGEMENT SCIENCES

Vol. 11, No. 3, 2021, E-ISSN: 2225-8329 @ 2021 HRMARS

role overload resulted in lowering employees' emotions, work delay, lower team morale, and no willingness to comply with rules, further affecting employee's centripetal force and organizational performance (Bianchi \& Milkie, 2010).

Organizational commitment indicates an employee's willingness to walk the extra mile for the organization's benefit (Akçakanat, 2020). The level and type of organizational commitment influence $s^{\prime}$ employees' desire and intention to stay or leave an organization. A study carried out by Nikolaou and Tsaousis (2005) is among those several notable studies on El's effect on organizational commitment and occupational stress indicated that employees with higher emotional intelligence can feel more valuable and less distressed. This fact was supported by Gardner's (2005) study, which investigated El and teachers' well-being founded a positive and significant correlation between oraganizational commitment and El.

\section{Leadership}

Effective leadership is crucial to meet Effective leadership is a crucial element to meet the changes occurring rapidly in organizations where $\mathrm{El}$ is identified as an important element for effectiveness. Transformational and transactional leadership attributes are among the various types of leadership attributes mentioned in this study. The transformational leadership concept may anticipate a model to interpret the relevance of emotions to leadership (Ashforth \& Humphrey, 1995). Bass et al (2003) indicated inspirational motivation, idealized influences, intellectual stimulation, and individualized consideration as four dimensions of transformational leadership; where transactional leadership consists of contingent rewards such as laissez-faire management, management-by-exception, and constructive transactions.

Goleman (1998) strongly argued that emotional intelligence is a prerequisite for successful leadership and indicated that individuals more prone to transformational leadership convey higher levels of El. Skills such as acknowledging the needs, feelings of subordinate individuals in organizations, wishes, identifying and relating to others emotionally, or arousing emotions for fostering changes and commitments are reflected through the study of El and leadership relationships (Ashforth \& Humphrey, 1995; Lindebaum \& Cartwright, 2010; McClellan et al., 2017).

\section{Conclusion}

The current study aimed to assess the impact of emotional intelligence on work-life balance and individual performance. Besides exploring the effectiveness of leadership as a moderator on the variables mentioned above, this study also focuses on specific criteria, for instance, regulation, self-judgment, family life, personal life, organizational commitment, and employee engagement. Implications for further research have been resulted from this study. Recommendations for future study are to examine different analysis units that might have been untapped, such as work-life balance, particularly for individuals playing multiple roles and contributing with more diligence. Moreover, management involved in encouraging the usage of leadership and work-life balance if various phases can also be accepted as a new dimension of the research field, which might contradict the current study findings. 
MANAGEMENT SCIENCES

Vol. 11 , No. 3, 2021, E-ISSN: 2225-8329 @ 2021 HRMARS

\section{References}

Akcakanat, T. (2020). The Effect of Happiness at Work on Organizational Citizenship Behavior: The Role of Intrinsic Motivation and Resilience. In Handbook of Research on Positive Organizational Behavior for Improved Workplace Performance (Baykal, E.), pp.179-200. Hershey, PA: IGI Global.

Ashforth, B. E., \& Humphrey, R. H. (1995). Labeling processes in the organization. Research in organizational behavior, 17, 413-461.

Ashkanasy, N. M., \& Daus, C. S. (2005). Rumors of the death of emotional intelligence in organizational behavior are vastly exaggerated. Journal of Organizational Behavior, 26(4), 1-12.

Bar-On, R. (1997). Bar-On Emotional Quotient Inventory: Technical Manual. Toronto, Canada: Multi-Health Systems.

Bar-On, R. (2006). The Bar-On model of emotional-social Intelligence (ESI). Psicothema, 18, 13-25.

Bar-On, R., Tranel, D., Denburg, N. L., \& Bechara, A. (2004). Emotional and Social Intelligence. In Social Neuroscience: Key Readings (Cacioppo, J. T., \& Bernston, G. G.), pp.223 - 237. New York, NY: Psychology Press.

Bass, B. M., Avolio, B. J., Jung, D. I., \& Berson, Y. (2003). Predicting unit performance by assessing transformational and transactional leadership. Journal of Applied Psychology, 88(2), 207-218.

Beauregard, T. A., \& Henry, L. C. (2009). Making the link between work-life balance practices and organizational performance. Human Resource Management Review, 19(1), 922.

Bianchi, S. M., \& Milkie, M. A. (2010). Work and family research in the first decade of the 21st century. Journal of Marriage and Family, 72(3), 705-725.

Boyatzis, R. E. (2018). The behavioral level of emotional intelligence and its measurement. Frontiers in Psychology, 9, 1-12.

Bozionelos, N., \& Singh, S. K. (2017). The relationship of emotional intelligence with task and contextual performance: More than it meets the linear eye. Personality and Individual Differences, 116, 206-211.

Brough, P., Timms, C., Chan, X. W., Hawkes, A., \& Rasmussen, L. (2020). Work-Life Balance: Definitions, Causes, and Consequences. In Handbook of Socioeconomic Determinants of Occupational Health: From Macro-level to Micro-level Evidence (Theorell, T.), pp.1-15. Cham: Springer.

Carmeli, A. (2003). The relationship between emotional intelligence and work attitudes, behavior and outcomes. Journal of managerial Psychology, 18(8), 788-813.

Cherniss, C. (2010). Emotional Intelligence: Toward Clarification of a Concept. Industrial and Organizational Psychology, 3(2), 110-126.

Cropanzano, R., Dasborough, M. T., \& Weiss, H. M. (2017). Affective events and the development of leader-member exchange. Academy of Management Review, 42(2), 233-258.

Day, A. L., \& Carroll, S. A. (2004). Using an ability-based measure of emotional intelligence to predict individual performance, group performance, and group citizenship behaviours. Personality and Individual Differences, 36(6), 1443-1458.

Demsky, C. A., Fritz, C., Hammer, L. B., \& Black, A. E. (2019). Workplace incivility and employee sleep: The role of rumination and recovery experiences. Journal of Occupational Health Psychology, 24(2), 228. 
MANAGEMENT SCIENCES

Vol. 11, No. 3, 2021, E-ISSN: 2225-8329 ๔ 2021 HRMARS

Druskat, V. U., \& Wolff, S. B. (2001). Building the emotional intelligence of groups. Harvard Business Review, 79(3), 80-91.

Emmerling, R., Boyatzis, R. E., \& Emmerling, R. J. (2012). Emotional and social intelligence competencies: cross cultural implications. Cross Cultural Management: An International Journal, 19(1), 4-18.

Extremera, N., Mérida-López, S., Sánchez-Álvarez, N., \& Quintana-Orts, C. (2018). How does emotional intelligence make one feel better at work? The mediational role of work engagement. International Journal of Environmental Research and Public Health, 15(9), 1-14.

Gannon, N., \& Ranzijn, R. (2005). Does emotional intelligence predict unique variance in life satisfaction beyond IQ and personality? Personality and Individual Differences, 38(6), 1353-1364.

Gardner, L. (2005). Emotional Intelligence and Occupational Stress (Doctoral dissertation, Swinburne University of Technology).

Goleman, D. (1995). Emotional Intelligence. New York: Bantam.

Goleman, D. (1998). Working with Emotional Intelligence. New York: Bantam

Grandey, A. A. (2000). Emotional regulation in the workplace: A new way to conceptualize emotional labor. Journal of Occupational Health Psychology, 5(1), 95- 110.

Gupta, S. (2016). Emotional intelligence and work life balance of employees in the information technology industry. Arabian Journal of Business and Management Review, 6(3), 1-5.

Harter, J. K., Schmidt, F. L., and Keyes, C. L. (2003). Well-being in the workplace and its relationship to business outcomes: A review of the gallup studies. In Flourishing: The Positive Person and the Good Life (Keyes, C.L.M. and Haidt, J.), pp. 205- 224.

Princeton: American Psychological Association.

Hogan, R., Curphy, G. J., \& Hogan, J. (1994). What we know about leadership: Effectiveness and personality. American Psychologist, 49(6), 493-504.

Isaac, R. G., Zerbe, W. J., \& Pitt, D. C. (2001). Leadership and motivation: The effective application of expectancy theory. Journal of Managerial Issues, 13(2), 212-226.

Janssen, O., \& Van Yperen, N. W. (2004). Employees' goal orientations, the quality of leadermember exchange, and the outcomes of job performance and job satisfaction. Academy of Management Journal, 47(3), 368-384.

Jordan, P. J., Ashkanasy, N. M., Härtel, C. E., \& Hooper, G. S. (2002). Workgroup emotional Intelligence: Scale development and relationship to team process effectiveness and goal focus. Human Resource Management Review, 12(2), 195-214.

Joseph, D. L., Jin, J., Newman, D. A., \& O'Boyle, E. H. (2015). Why does self-reported emotional intelligence predict job performance? A meta-analytic investigation of mixed El. Journal of Applied Psychology, 100(2), 298-342.

Koubova, V., \& Buchko, A. (2013). Life-work balance: Emotional Intelligence as a crucial component of achieving both personal life and work performance. Management Research Review, 36(7), 700-719.

Kreiner, G. E., Hollensbe, E. C., \& Sheep, M. L. (2009). Balancing borders and bridges: Negotiating the work-home interface via boundary work tactics. Academy of Management Journal, 52(4), 704-730.

Laka-Mathebula, M. R. (2005). Modelling the relationship between organizational commitment, leadership style, human resources management practices and organizational trust (Doctoral dissertation, University of Pretoria). 
MANAGEMENT SCIENCES

Vol. 11, No. 3, 2021, E-ISSN: 2225-8329 @ 2021 HRMARS

Lam, L. T., \& Kirby, S. L. (2002). Is emotional intelligence an advantage? An exploration of the impact of emotional and general intelligence on individual performance. The Journal of Social Psychology, 142(1), 133-143.

Lan, J., Wong, C. S., Jiang, C., \& Mao, Y. (2017). The effect of leadership on work-related flow: a moderated mediation model. Leadership \& Organization Development Journal, 38(2), 210-228.

Lawler III, E. E., \& Suttle, J. L. (1973). Expectancy theory and job behavior. Organizational Behavior and Human Performance, 9(3), 482-503.

Leaper, C. (2011). More similarities than differences in contemporary theories of social development? A plea for theory bridging. Advances in Child Development and Behavior, 4 , 337-378.

Lindebaum, D., \& Cartwright, S. (2010). A critical examination of the relationship between emotional intelligence and transformational leadership. Journal of Management Studies, 47(7), 1317-1342.

Luthans, F., \& Youssef-Morgan, C. M. (2017). Psychological capital: An evidence-based positive approach. Annual Review of Organizational Psychology and Organizational Behavior, 4, 339-366.

Mayer, J. D., \& Salovey, P. (1995). Emotional intelligence and the construction and regulation of feelings. Applied and Preventive Psychology, 4(3), 197-208.

Mayer, J. D., Salovey, P., \& Caruso, D. R. (2000). Models of Emotional Intelligence. In Handbook of Intelligence (Sternberg, R.J), pp.-396- $\quad 420$. Cambridge: Cambridge University Press.

Mayer, J. D., Salovey, P., Salovey, P., \& Sluyter, D. (1997). What is emotional intelligence. In Emotional development and emotional intelligence: Implications for educators (Salovey, P. and Sluyter, D.J.), pp.3-31. New York: Basic Books.

Mayer, J. D., Caruso, D., \& Salovey, P. (1999). Emotional intelligence meets traditional standards for an intelligence. Intelligence, 27(4), 267-298.

McClellan, J., Levitt, K., \& Di Clementi, G. (2017). Emotional intelligence and positive organizational leadership: A conceptual model for positive emotional influence. Journal of Behavioral and Applied Management, 17(3), 197-212.

McColl-Kennedy, J. R., \& Anderson, R. D. (2002). Impact of leadership style and emotions on subordinate performance. The Leadership Quarterly, 13(5), 545-559.

Miao, C., Humphrey, R. H., \& Qian, S. (2018). A cross-cultural meta-analysis of how leader emotional intelligence influences subordinate task performance and organizational citizenship behavior. Journal of World Business, 53(4), 463-474.

Parkes, L. P., \& Langford, P. H. (2008). Work-life bal ance or work-life alignment? A test of the importance of work-life balance for employee engagement and intention to stay in organisations. Journal of Management \& Organization, 14(3), 267-284.

Pekaar, K. A., van der Linden, D., Bakker, A. B., \& Born, M. P. (2017). Emotional intelligence and job performance: The role of enactment and focus on others' emotions. Human Performance, 30(2-3), 135-153.

Praya, S. M. J., Ghosh, A., Isaac, O., \& Jesuraj, S. A. V. (2019). The Impact of Emotional Intelligence on Work Life Balance among Pharmacy Professionals in Malaysia. International Journal of Management and Human Science, 3(1), 29- 34.

Rafnsdóttir, G. L., \& Heijstra, T. M. (2013). Balancing work-family life in academia: The power of time. Gender, Work \& Organization, 20(3), 283-296. 
MANAGEMENT SCIENCES

Vol. 11, No. 3, 2021, E-ISSN: 2225-8329 @ 2021 HRMARS

Rangreji, D. D. (2010). A study on emotional intelligence and work life balance of employees in the information technology industry in Bangalore, India (Doctoral dissertation, Christ University).

Salovey, P., \& Mayer, J.D. (1990). Emotional Intelligence. Imagination, Cognition and Personality, 9(3), 185-211.

Sharma, L. N. (2014). Emotional Intelligence as corelate to work life balance (A case study of Sidhi MP). Global Journal of Finance and Management, 6(6), 551-556.

Shylaja, P., \& Prasad, C. J. (2017). Emotional intelligence and work life balance. Journal of Business and Management, 19(19), 18-21.

Smigla, J. E., \& Pastoria, G. (2000). Emotional Intelligence: Some have it, others can learn. The CPA Journal, 70(6), 60.

Sonnentag, S. (2003). Recovery, work engagement, and proactive behavior: a new look at the interface between nonwork and work. Journal of Applied Psychology, 88(3), 518528.

Sony, M., \& Mekoth, N. (2016). The relationship between emotional intelligence, frontline employee adaptability, job satisfaction and job performance. Journal of Retailing and Consumer Services, 30, 20-32.

Sunil, K., \& Rooprai, K. Y. (2009). Role of emotional Intelligence in managing stress and anxiety at workplace. Proceedings of ASBBS, 16(1), 163-172.

Trevor, C. O., Gerhart, B., \& Boudreau, J. W. (1997). Voluntary turnover and job performance: Curvilinearity and the moderating influences of salary growth and promotions. Journal of Applied Psychology, 82(1), 44-61.

Tsaousis, I., \& Nikolaou, I. (2005). Exploring the relationship of emotional intelligence with physical and psychological health functioning. Stress and Health: Journal of the International Society for the Investigation of Stress, 21(2), 77-86.

Vroom, V. H. (1964). Work and motivation. San Francisco: Jossey-Bass Publishers..

Wayne, J. H., Butts, M. M., Casper, W. J., \& Allen, T. D. (2017). In search of balance: A conceptual and empirical integration of multiple meanings of work-family balance. Personnel Psychology, 70(1), 167-210. 